\title{
明治末期より昭和期に至る劇場空間の近代化に関する研究 前舞台領域の空間的変遷
}

\author{
A STUDY OF MODERNIZATION IN THE THEATER FROM \\ THE LATTER MEIJI ERA TO THE BEGINNING \\ OF THE SHOWA ERA \\ -The process of a forestage-
}

永井聡子*，清 水裕之**

Satoko NAGAI and Hiroyuki SIMIZU

\begin{abstract}
From the latter Meiji era $\omega$ the beginning of the Showa era, the space between stage and auditorium goes foward two dipromatic directions in Japanese theatre with getting of the high position in the process from a diplomacy to an amusement than before. These directions in the Kabuki theatre begin with Shingeki. Kabuki theatre and Shingeki theatre have different ways each other. That is synbolized by Hanamihci , Lighting of $\mathrm{FOH}$ (front of house)and kuppethorizont.
\end{abstract}

Keywords : forestage, prosceniumarch, stage lighting, Hanamiti, Ginkyo, kuppelhorizont 前舞台、プロセニアムアーチ、舞台照明、花道、銀橋、クッペルホリゾント

1.はしめに

1-1. 研究背景・目的

明治44年の帝国劇場建設から、関東大震災を挟み東京宝塚劇場誕 生の昭和 9 年に至る我が国の演出空間と劇場空間において、特に前舞 台領域に注目し、既存の歌舞伎劇場に見られた劇場構造の変形経路 を軸に近代化された劇場空間の姿を明らかにすることを目的として いる。前舞台領域とは、ここでは舞台と客席をつなぐ空間と設定 し、特に舞台前の処理にその特徵を見るものである。本論における 言葉の使用は、「演出空間」を「物理的な意味で演技の及ぶスペー ス」、「劇場空間」を「舞台と客席を含む空間」とし、また「近代 化」を「劇場の外観、内観などに西洋の影響及び我が国独自の改良 が見られること」，を指すものとする。

明治末期から昭和期に至る劇場空間では、歌舞伎と新しい演劇 ジャンルの併存、西洋近代の演劇の演出手法の併存、舞台額緣内の 照明の充実に伴う客席空間からの投光を中心に検証する。客席から の投光に関しては、FOH＜Front of house＞（前あかり）1の概念を用 いてその扱いに対する対応を検証する。

なお本論では、明治末期から昭和期に至る東京の劇場空間を対象 としている。また、舞台と客席との関係、舞台美術、照明との関倸 を概念的に捉え導き出すことに主眼を㯰いたため、時代の変化に伴
い特徵を示した劇場を取り上げることとした。

\section{1-2. 既往の研究}

劇場史に関する研究は、後藤慶二『日本劇場史』2、須田敦夫『日 本劇場史の研究』、竹内芳太郎『日本劇場図史』4がある。しかし これらの著書は芝居の創始期から始まって、明治・大正期の歌舞伎 までを中心に扱っている。また古代から近代に至るまでの劇場空間 を通覧したものに、佐藤武夫『オーディトリアム』S、小谷意之助 『現代の劇空間』听あるが、何れも演出理念や舞台美術（装置、照 明など) と劇場空間との結びつきまで言及したものではない。特に 近代においては舞台照明の分野が演出の一要素として重要な位置を 占める。舞台照明と劇場建築との関保について言及した著書には、 遠山静雄の『舞台照明学上下』8があるが建築空間への言及には及ば ない。また日本の伝統芸能における舞台と客席との関倸に関する研 究に清水裕之『劇場の構図』放ある。

1-3.分析対象・方法

本論では、対象とする劇場の写真、図面から読み取れる前舞台領 域の空間的変遷について検証するにあたり、当時の演劇人など劇場 に関係した人物の言説を考察し、劇場関係者へのヒアリングによっ て補足している。
$*$ 名古屋大学工学部建築学科 大学院生·文修

** 名古屋大学工学部建築学科 教授. 工博
Graduate Student, Dept, of Architecture, School of Engineering Nagoya Univ. M. Art.

Prof., Dept. of Architecture, School of Engineering, Nagoya Univ., Dr. Eng. 


\section{2. 珟場建設の背景}

我が国における酸場空間の西洋化への主張は、文学、美術の欧化 風潮に㙨を同じくして、明治19年の「演㱆改良会」発足に端を発す

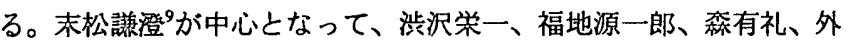
山正一、依田百川、矢田部良吉、矢野文雄など政治家・実業家が 揃った。伊藤博文、西園寺公望、陸舆宗光、田口那吉、未広重恭ら の多数の賛助を得て設立されたことだけを見ても、菅井幸雄が『近

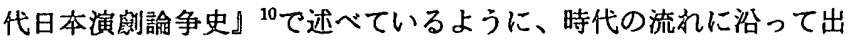
てきたこの「演劇改良」は、上層階級からの穦極的な“文化改良” への姿勢が読みとれる。中でも末松謙澄が同年出版した『演睑改良 意見』 ${ }^{12}$ には、“西洋かふれ”とも受け取れる劇場空間の西洋指向 が窥われる。ここては「花道不要」が提唱されているがこの点こ そが我が国の劇場空間における「変形経路」の中核をなするのであ る。東の歩み (仮花道) の廃止だけてなく、花道そのものの存続問 題まで引き起こしたのである。

劇場の本格的洋風化は、新䭘に使用された高等演芸場でる有楽 座（横河民博設計、舞台間口6間）とされている。㓺場の外観、内 観のみならず即場経営においても新しい時代に向けて刷新があっ た。 ${ }^{11}$ 䒩屋制の撤廃、上演時間の変更、下足での出入り、切符制 度、低料金化、幕間休馣時間の短縮、食堂の設置など、殷場での観 客の過ごし方に近代性が持ち込まれ今日見られる㓺場の体制に様変 わりした。明治44年開場を迎えた帝国劇場（民間資本）において、 「世界列強に恥じない㓺場の建設」「中層階級にも受け入れられる 高尚なる芸術」 ${ }^{13}$ という名目で、外観・内観、舞台設備など創場建 築において本格的な西洋化が始まった。西洋のオペラ㱆場を模した とされる外観の洋風化、照明設備などの充実に伴うアメリカ、ドイ ツからの機材の導入、付属の俳侵学䒔、楽隊、背景部の設置など改 良が内外共に実行に䔟された。これらは我が国における文化の变わ り目を如実に物語っている。特に照明分野で、「舞台電気係」と して置かれていた我が国の舞台に、帝国劇場で舞台照明担当の技術 者が置かれたことを契僟に、「舞台照明」という名称及び職能が定 着していく。その背景には、有楽座や築地小劇場での新殷による照 明への追求にその影響があることは見逃せない。東京高等電気学焚 出身て横河工務所にいた夯文逸は、帝劇の電気主任に拻擢され、帝 栃入社後欧米へ照明装置を見学するために派遗されている。14 帝 㔊で初めて舞台照明に学識ある技術者（秀文逸）が担当するような

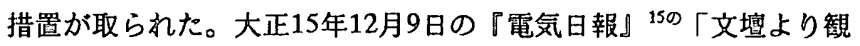
たる舞台照明」には小山内薰の昋に対する言葉が奇せられている、

「由来、演出者の立場から云へば舞台照明の衝にあたる者は、矢 㖘り演出者自身が盖成した人々を以てすると云ふのが、理想てあり 又今日ては較、此の理想の實現が可能とせられて舞台照明の上に一 進步を佋らして居る、然るに以前は左様ではなく、演出者と照明技 術者亡の意思の疏通が不十分であつたが為めに、隨分图つたと云ふ 幾多の實例があった。夸君と私の場合は左様ではなくて、秀君の維 密なる設計によって、舞台照明が完全に行はれたと云ふ一例であ り、...

演出家と技術者との連携に重要度を認めたことを示す言説であり、 舞台照明分野の確立における近代化の重要な点である。
この間に起こった関東大震災は㱆場空間にも一つの転機として存 在する。歌舞伎座など東京におけるほとんどの㓺場を壊隇状態にし たか、この災害を契機に建設された劇場では、帝国劇場、歌舞伎座 の改修に見られるように鉄筋コンクリート造を採用した設計が始ま る。また大正 13 年開場の築地小劇場は、仮設興行場取締規則（大正 12年9月)によりバラック建築ではあったが近代劇場の要素が㠜縮 された形て建設されることとなった。震災後、演㱆の中身について 三宅周太郎によれば、「これは不幸に退歩でこそあれ、そこに進歩 は見られなかったのである。」 ${ }^{16}$ と述べているように演劇界として は全体的に低迷したが、新刻 ${ }^{17}$ 常打ちの小屋を有する築地小即場 の活動はそれを好況に向かわせる契機となった。明治以後、「演創 の実験室」「民衆の見世物小屋」として出発した劇団築地小剆場は

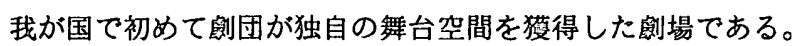

钢場に対するまた別の新しい方向性は、レビューというジャンル の殷場空間において昭和 3 年東京に新しく膚団と㱆場が一体となっ た如楽施設の構想にその芽があった。東京宝塚劇場が昭和9年1月1 日、宝塚少女歌跑団 ${ }^{18}$ 東京ての常打ち小屋として開場したのてあ る。宝塚少女歌即は第一回帝創公演（大正7年）て東京初進出を果 たしている（帝即歌鲗部（開場から半年後の8月25日発足）はすて に二年前に解散）。当時東京ては浅草オペラが全盛て、帝㓷の特別 公演（五日から十日）ては需要に応じきれず、市村座、歌舞伎座、 新橋演舞場に進出して一ヶ月公演を打つようになっていた。 ${ }^{19}$ 宝塚 少女歌劇団は兵庫に誕生し、その常打ち小屋である宝塚大劇場は大 正14年に建設されている。時期としては東京よりも早いが殷場空間 としての独自性を定着させたのは東京宝塚の方である。栾京宝塚劇 場が資本家小林一三によって「有楽町アミューズメントセンター構 想」の一環として建設されたという点においても、新しい庶民の殷 場建設として、また都市計画の一環として興味深い。「東宝劇場、 有楽座、日比谷映画劇場亡三居並立して、日比谷に高尚なる新哭楽 地帯を作ることは、時勢の要求であり、又東京市民に対する福音て あると信じて居ります。」「市民の利益の為に」「国民大衆に対す る高尚なる娛楽と㓪安の為に必要なる機関として」「大東京市民の 為に一家団樂家庭本位」「風紀上公明正大なる娛楽地帯」とは、昭 和9年8月25日第四回株式総会に於ける、社長小林一三の文脈に登 場した言茧である。 ${ }^{20}$ 劇場は、明治まで娛楽の場として庶民に支 えられ、政府には「悪所」としての扱いを受けた芝居小屋か、時代 と共にそのイメージを一掃していく過程が窥われる。

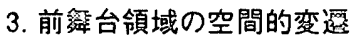

3.1 歌舞伎の劇場空間における基本概念の变換

睑場空間の变遷を辿るとき、その劇場形態の相違は創造者亡観客 との結びつき方に関する問題と言うことができ。日本の空間構成 の場合、現在では構造的側面が姯神的側面に影響を与えるものとし て大まかに以下の3つの点にまとめられる。

1）舞台と客席の構造的違いが䄇神的側面に影響を与え、それが親 密さに関わる場合 $\rightarrow$ 花道の使用

2）プロセニアムアーチによる舞台と客席の分離によって、一種観 客に隔㕍された感を与える場合 $\rightarrow$ 第四の壁理論；舞台内におけるパ フォーマンスの完結性之同時に観客の形式の容認（観客は外部から 部屋の中をのぞき見るスタイルの受容） 
3）舞台と客席が演出の多様性に対応した構造的処理によって舞台

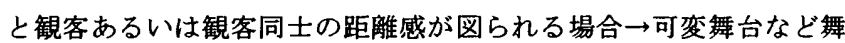
台の構造的多様性一

明治末期から大正、昭和期に至る我が国の空間構成は、歌舞伎劇 場に見られる 1）の状態から2）の状態への移行期にあった。次第 に、2）の状態は支配的になるが、一方向からのみ観られるという 状態が見えない部分でのからくりの熟練さを磨くことにもなり、結 果として総合芸術として舞台演出の技術的分野を躍進させることに もなった。それまで舞台と客席の融合関倸に親しんでいた我が国の 劇場空間がプロセニアムアーチによって分離され、さらに鉄筋コン クリート造の採用によってその区画も強化されるに至る。歌舞伎の 劇場空間の変化は、まず明治に入って舞台前の付け舞台とされてい た部分が拡大されいわゆる舞台と客席の区画の形成に向かい、羅漢 台が完全に消滅するなど舞台と客席の分離への兆しが見えてくる。 客席も桝席に代わる椅子席の採用と共に、空間が決定的に均質化一 向かう。この点に関して、明治45年4月7日『読売新閏』に揭載され た、クウルト・グラアザ「日本の劇場の舞台透視法（木下圭太郎 訳）」（後木下本太郎『地下一尺集』の中に収録される）" 違いに関する所見を見ることができる、

「日本では、栈敷に当たる小さい妌があるのであるが、一定の方向 があるのではなく、見物は演劇の経過上必要な方向を取るのであ る。と云ふのは、この花道の上では単に人物の出入りがある許りで なく、往々戲曲の重要なる一節が演ぜられるので是非さうなるので ある。（中略）かかる場を見ると、この全堂が演劇の為に存する 事、並びにそこに一定の方向のなき事、従ってまた舞台上の遠近法 の欠如して居る事などが能く分るのである。」

と述バられているように、椅子席の採用は、単に生活態度に变化を もたらしただけでなく、我が国に置いて観劇態度を根本から覆す大 きな要素であると言え、花道を特徵とする前舞台領域の変化に拍車 をかけた。これは近代化の大きな要素である。大正期に至って鉄筋 コンクリート造の採用によるプロセニアムアーチ導入が定着し、観 劇の一方向性がさらに强化されることとなった。しかし、花道はそ の存在を消减させることなく現在に至っている。花道の意味を考え るとき、空間の均質性は存在しないという前提があり、歌舞伎劇場 のこの不均質性が舞台と客席の融合を促していた。花道は、俳優の 行くという時間を強調する意味以外に、“舞台と観客との親交”を 促すという意味を持っている。しかし、花道の作用にもう一つの側 面がある。観客は観客席を貫く構造に対し近距離にあるが、不可侵 の心理的な「遠さ」を認識している。22 花道に対する意識の二重 構造は、空間的には近くにあるが花道の舞台と同じ高さを有するが 故の精神的遠さも与えていると言え、舞台から観客席を貫いている と同時に、基本的に舞台空間に属しており、観客席の通路を利用し た演出方法と根本的違いを見ることができよう。つまり、花道が舞 台に属し、観客が侵入してはいけない空間を前提としているのに比 心、客席を利用した演出方法は、もともと客席の通路を利用してお り、舞台空間に属してはいない。芝居が終われば観客の通路となる という点が指摘でき2. れる。花道を有する劇場空間は、舞台への観客の視線だけでなく、
花道を挟んで観客同士の視線が交差する。幕が降りて花道に残った 俳優の演技に集中するような場面では、両脇からの観客の視線が交 差し、観客は花道上の俳優とその向こうにいる観客とを認識するこ とになる。この意味において歌舞伎の劇場空間は不均質である。 従って、西洋における劇場空間のように基本的に、遠近法の理念に 基づいて一消失点をもち、舞台に向かって理想的な視点を生じさせ る空間では、観客の視線はできるだけ理想的な視線を確保するため に㯰かれる。そこでは空間は均質なものとなることが蚛調され、こ こに両者の基本的相違が存在する。このような構造上及び精神的側 面に与える基本的相違があるにもかかわらず、舞台と客席との分離 はこの明治期から昭和期に至る間に完成される。従って、歌舞伎劇 場で特徴を示していた大臣柱が新劇により装置化に向かい、大臣柱 と花道のとの間の空間が形成していた前舞台領域は、プロセニアム アーチの中に後退することになる。しかし一方で、舞台と客席との 融合も模索されるようになり、築地小劇場という仮設劇場での実験 的試み以外では、昭和に入って東京宝塚劇場というレビュー劇場誕 生にその実現を見ることができる。その過程において、花道は変形 されるとともに、照明の発達が劇場構造に変化を与え近代化された 空間を形成する。

图1.劇場空間の変橎概略図

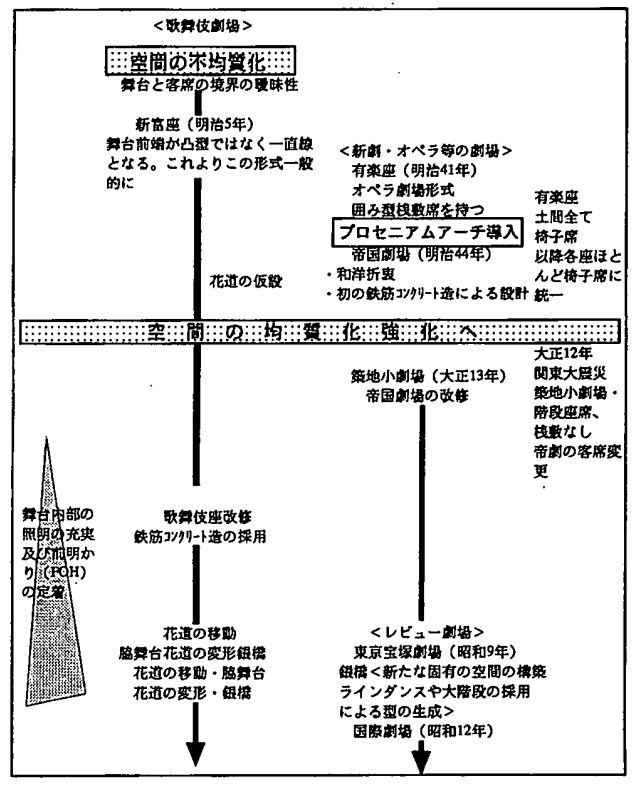

図2. 歌舞伎剭場の形態变化

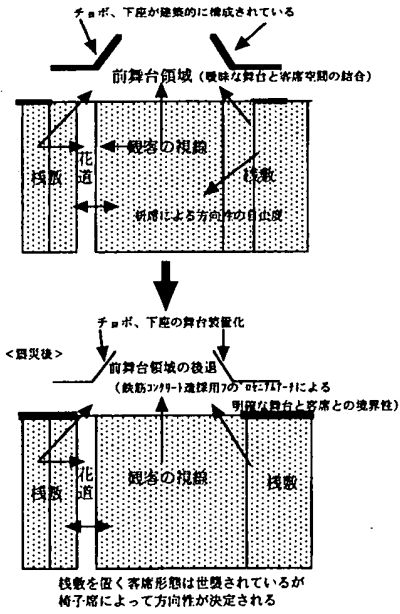


3-2. 新しい演郕ジャンルの併存に伴う花道の移勒と变到

花道は、歌舞伎以外のジャンルを上演する時代に入ると、「移 動」あるいは「变形」の経路を辿る。ここに用いる「移爿」とは、 花道を「下手側観客席後方から锶客席を通して舞台へ通じ、台 の延長として主要俳侲の哖台への登退場に重要な役割をもつ設備」 24 とする埸合、棈造的「移動」を指す。また「変形」とは、銀槅に 代表されるように「舞台と観客との融合」を目指す目的で設慨され たもので、花道の形態（江戸中期に完成された形態）を止めていな いものを指すこととする。

明治末期になって、歌舞伎のみを上演する均埸、有楽座や旧帝国 即場（以下、帝即）のようなより本格的に歌舞伎以外のジャンルも 上演可能な空間、そして演郕人が実験的試みのできる築地小瞅埸

（以下、築地）のような形態の出現以外には、邦楽座、帝国ホテル 演芸場、三越百貨店のホール、あるいは公会堂といった、舞台芸術 以外の目的にも使用できる空間として存在していた。ここでは、こ

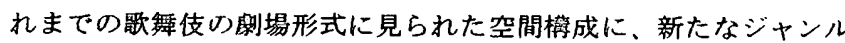
が組み合わされた空間を持つ帝則、新郕の空間として特徵を示した 笨地、そしてレビューのために帮造化された上演の場を実現した東 京宝塚荗場を時代を代表とする瞅場として、花道の存在を上演ジャ ンルの䔔いから検証する。

(1)歌舞伎と新しいジャンルの併存

花道は、明治44年開埸の帝涠（横河民戟設計、舞台間口8間）に おいて、歌舞伎及び新即、オペラの異ジャンル併存により大きく変 化する。その特街として、プロセニアムアーチによって舞台と客席 の分離の明確化が行われ、アーチ内に納まることによって大臣柱は 装置的扱いを受けるようになる。オーケストラピットや囲み型栈放 席を持つオペラ攸場形式の空間に花道が斜めに仮設で設置され和洋 折怙となった。これは歌舞伎以外のジャンルにも使用できるように したものであり、花道や大臣社だけでなく、オーケストラピットも 仮設となった。帝劇建設以前の明治41年には内外共に西洋化された 有楽座は（横河民輔設計）、主に新劇に使用され、帝畔に設置され た花道はない（開場初期には舞台床が傾斜していたいも特徴）。

帝即が歌舞伎と新しい演劍ジャンルの併存となったのは、当初オ ペラに額するものを上演するはずであったが、経営上歌舞伎を除い ての興行には困難を生じるという状況があった。25 結果として、 誔生した「和洋折㖜」の睑場空間において、舞台額縁周辺に見られ る装飾は外国の即場に見劣りしないという意䊅での政治的な性格を 物語るものであるが、帝測の花道の設置について、議諭が 6 ケも 要したことは当時の時効から歌舞伎郕場の姿に悔れ親しんだ我が国 の混乱した様子を物語っている。20島村抱月の「木に竹を接いだよ うな花道の使い方」27という言説はその状況を代并している。

\section{(2)新郕の劇場}

大正13年開場の築地（中栄一徹、浦田竹次郎設計、舞台間口5間 半）の空間挬成は、19世紀末から20世紀初頭にかけて起こった梯々な

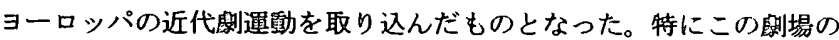
場合その建設に際し、土方与志、小山内蕉、和田崝など演剆人の海外 見閏によって、様々な要素が取り込まれているのが特徴である。

花道は舞台左右の両脇花道として若干の姿を止めている(これは 従来の花道に比べると短いものであるが演楽人の認識は花道であっ た）。歌舞伎の花道が姿を消すことによって、空間の方向性はプロ
セニアムアーチの中だけでなく、栈敂を除き年台開口幅と同じ幅 の客席からどこからも舞台に封して垂直となるよう階段座席とし たことによって、锯台への一方向性に配唇がなされている。一 方、前舞台領域に設居された両側の花道とその背後のアーチから 登退埸することにより、また娒台前端に階段を設け客席に連絡す るようにしたことによって、プロセニアムアーチからの脱出を試 みようとする指向性も窥われる。近代に拄ける演出方法の空間的 共存が見られるが、このように作品とその演出法に従って融通性 が図られたことは、甽場本来の姿として考えるべき部分である。 (ろレビュー膚場

昭和9年開埸の東京宝塚邻埸（竹中工務店・㠇尾九郎設計、舞台 間口13間) では当初銀橋はないが、銀橋の設㯰は東京宝塚㓺埸建 設のため阪急電鉄の眵場建設に関わるメンバーによる昭和 3 年にア メリカ、フランス、ドイツなどーヶ月を要寸很場視察が背景にあ る。 28 この視察の収秽として東京宝塚既場での最初のレビュー作品

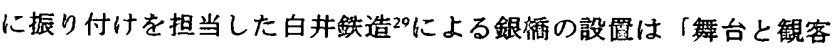
の親密さ」を助けるものという意味に固いて花道と同じ性格を持 つものでありその变形と言えよう。銀橋はパリのレビュー䭅埸

(アメリカのミュージカルにパリの影響を感じていた）で見た銀 橋が、欧米視察㷌国後第3作「ローズ・パリ」演出の祭、宝塚大即 場で銀楿を取り付け大好詳を得ることに成功したため、これを東 京宝冢甽場にも設羁することにしたとされている30。舞台両端に設 けられた脇花道は、花道の移動を示すような形態となっている が、実際の使用に關しては、“世界最大の間口”（使用時には 「最曼124尺の間口」 ${ }^{31}$ ) と銘打っているように、後ろのスペース も舞台として使用可能な点からレビューならではのスペクタクル 性への追求と言え、その後の公共ホールに設膡されたような舞台 両脇花道とは性格を異にする。そして両脇花道の上階に投光ス ベースを設けることが可能となったという点においては、舞台照 明の分野の前進となった。東京宝塚劇場に見られる花道の变形

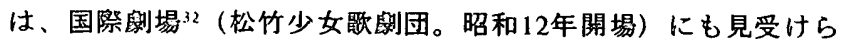
れ、其にレビュー則場に設置されている。

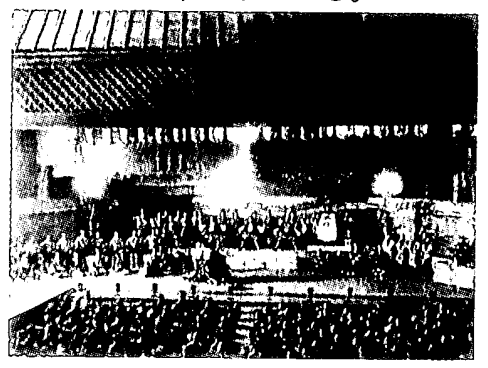

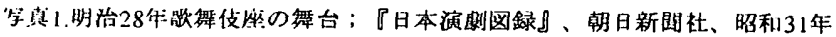

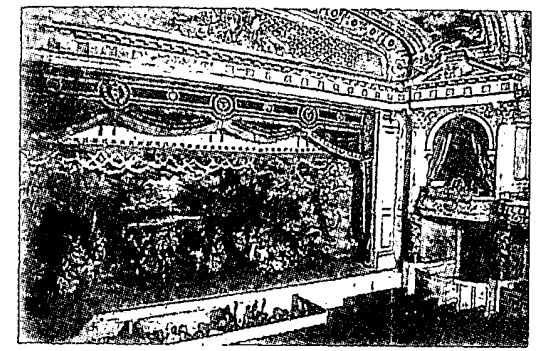

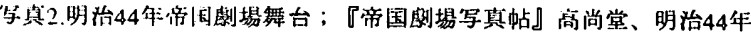
(オーケ자ヒ・゙・と共に、左端に花道が見える) 


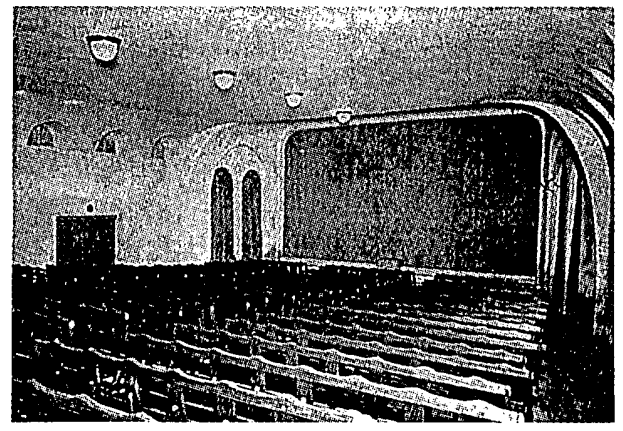

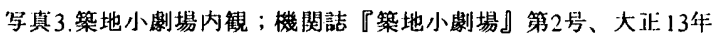

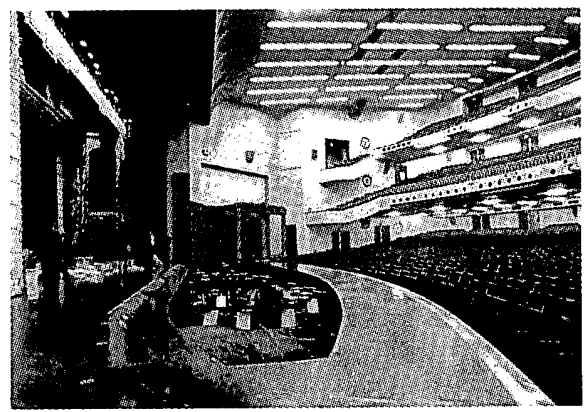

写真4.東京宝塚殷場内倠； (平成9年著者撮影・昭和9年当時の構造を残す)

\section{3-3. 舞台照明分野発達の第一歩}

花道の存在の考察からここで、舞台照明の分野に焦点を当ててみ たい。劇場空間の近代化への道は、我が国でもこの光の力によると ころが大きいからである。花道の形態による構造的変化と同時に、 演出上における光の問題は、客席空間に調光室を設けるという空間 的影響を与えた。また花道の設置に左右される舞台と客席との融合 状態を、光という実体のないもので融合を図ろうとする、まさに演 出の時代に入っていくその端緒的過程にあるとも考えられる。

舞台照明の進歩に関して、我が国では欧米に比へ、昭和期に至る まで産業として成立していなかったこと沙、およびその努力は極め て私的活動としての歩みであったことを念頭に検討を進める必要が ある。それが表舞台に立つのは、土方舞台装置研究所 ${ }^{34} て ゙$ 実験を重 ねた努力が、築地において開花したときで、時代は大正も末期で あった。昭和に至るまでの大正期は演劇人の陰での地道な研究に 依っていたため、劇場空間における照明の前進は、有楽町界隈の新 しい「庶民の娛楽の場」というアミューズメント構想を実現した、 小林一三の経営方法による東京宝塚劇場建設まで待たなければなら ない。我が国の照明設備向上の実現が連れた理由を、遠山静雄は 『舞台照明五十年』の中で、資本家に思い切った改善の熟意が無 かったことや伝統的歌舞伎劇上演の観念が新しい演出効果に対する 意欲を減退させたことを挙げ、照明設備の新設に当たってその意義 を従属的なものに考え、築地が考えた程演劇的重要性を頭に入れて 設計に当たらせなかったことによるとしている。3s 従って、我が 国の舞台照明分野の進歩は昭和になってからのことで、明治末期よ り大正、昭和に至る時期は、歌舞伎劇場に見られる状態からの脱皮 というプロセスを歩んだにすぎない。しかし、劇場空間における基 本的概念の相異を考えてみれば、この一歩は後の劇場空間に対して 大きな前進であったと言えよう。

FOH（前あかり）からの照明の発展に特徵があり、その必要性は
舞台内の照明設備の充実に関係している。舞台照明に関する観劇の 基本は、FOHの基本理念である「観客が舞台の事物を見ることがで きること」で、この条件を満足する基本的配光は、観客に対応する 舞台の立面に対し客席側から水平方向の光が与えられることであ る。舞台内部の照明設備だけでは前舞台の照明に不備が生じる。ま た、フットライトだけでは下からの投射であるため人物の顔面に不

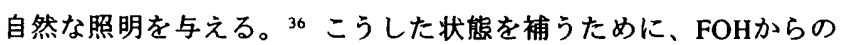
照明がある。FOHからの照明は、舞台立面に対し水平方向の光であ るため舞台面の照明効果は平板なものとなるが、舞台画面を均質な 明るさで見せるような、基本的に歌舞伎や透視画法等絵画的装置に 対しては有効なものである。 ${ }^{37}$ 一般的に舞台に向かって水平方 向、あるいはそれに近い角度で光を与える多くの光源を客席内部に 設置することは実際上困難であるため、客席天井ならびに両側壁を 使用することになるが、大正末期頃までは客席からの投光は仮設で あった。現在客席からの投光はそのスペースにおいて客席天井や客 席左右の側壁に設けられているのが通常である。即ち、シーリング ライトとフロントサイドライトの設直とその执充である。帝劇より 少し前に建設された有楽座において、ボーダーライト、フットライ ト、ストリップライト、バンチライトなどが設置されたが ${ }^{38}$ 、客席 からの常設の投光設備に関する記述はない。現代の劇場においては 主としてシーリングライトとフロントサイドライトは、遠山静雄に よれば大正11年市村座（高原弘造設計）で初めて照明設備を行った

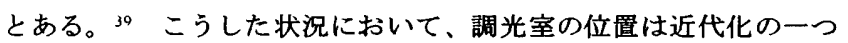
の特徽である。もともと電気部屋と呼ばれ、大臣囲いのお囃子部屋 の2階などに設置されていた。帝劇は最も進歩した照明設備の劇場 と言われていたがその位置に変わりはなかった。40大正10年頃に は劇場の天井を一枚はがしてそこ一投光器を取り付け、客席の両脇 2階栈敷前からも投光器を取り付けるといった舞台照明であった が、当時これ以上のものはなかった。つまり客席側に投光室を設け たのは穼地が初めてである41。これはそれまでの緞帳と大臣囲いの

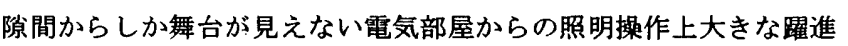
があったのであり、必然的に劇場建設計画に大きな影響を与えるこ とになった。昭和 5 年開場の東京劇場では客席からの投光を採用す るためにフロントサイドにある贵䆭室 ${ }^{42}$ 投光室にしてしまう例も あったが、昭和 9 年に開場した東京宝塚劇場では舞台両脇花道延長 線上にある中二階を投光室にすることを実現している。東京宝塚劇 場に代表されるレビュー劇場の建設に伴って客席からの投光は、現 代に見られるような対応となった。また築地のホリゾントライトの 効果も欧米での試みから10年経ていたとはいえ、この頃より我が国 では照明の創造性に対する姿勢が賽えるのである。

歌舞伎に使用された陰影のない背景から照明を駆使した表現方法 八の転換の間に油絵画法を採用した時期があったが、著名画家が舞 台に登場したその活動は東京美術学校教授の採用など帝劇の背景部 誕生の背景となった。 ${ }^{43}$

「背景並びに道具は一新機軸を出せり。背景は主に油絵を持ちひ、 張り詰めたるまま日覆の上に吊り上ぐるの仕組み也。」44

舞台美術の近代化は、まず背景画（油絵）と舞台照明の誕生の組み 合わせから始まったが大正末期にはすでに時代遅れとなり、照明に 
その位圈を临われる。陰影の付いた平面的絵画との併用では照明の 動的側面は生かされない。海外においても明治末期には、照明の性 格である「見えること」以外の演出効果に対する追求が行われてい た。その代表と言えるのがイギリスのゴードン・クレイグの演出で あり、スイスのアドルフ・アッピアの理論である。筑地でも当然彼 等の活動に対する理解があった。小山内蕉は『舞台芸術』の中で次 のように述ぺている、

「 (略) 既にクッペルホリソントの発明がある。ルントホリソント の発明がある。一魂の小丘、織小なポプラの一本一もうそれだけ で、絵画以上の効果が得られる時が来ているのである。単に絵画の 方面のみではない。」45

舞台照明は着実に演出上重要な位置を占め始める。現在のように 技街を体得し芸術的䶂境を創造する照明家という職種は無く、電灯 が螎場に入ってからも、歌舞伎の世界では舞台照明の進歩発展に寄 与する面は殆どない。歌舞伎は古典形式を世蟹するという立場を とっていたため、照明の進歩は新痪によって行われることとなっ た。遠山静雄は『舞台照明五十年』40の中で、照明設備の導入に関 して帝劇、築地以外の㓻場において見るべきものはないと述べてい る。関東大霞災後の大正13年5月22日付『東京日々新闕』の䈥地小 甽場に関する記事に「新しつくめで警か寸築地小甽場」「照明も見 物席も万事新機軸」という見出しが付けられ仮設铝場ながら画期的 な出来豪であったことを伝えている、

「(略) (1)観客席の頭上からと舞台両側からの光線で照明を行ひ、 在来の栈敫のものを廃して観客席は舞台の幅とおなじくし観客は常 に舞台に対して直角である訳で、その他(2)舞台装固についても星零 を完全に表現する享が出来るといはれている」

下線(1)から、客席天井からの投光を指し図面からも確認できる。開

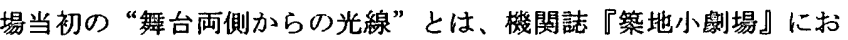
ける和田精の「両側のアーチの柱から舞台の正面に向けて照らす設 備がある」という記述と一致する。また、水品春樹は『小山内㲘と 築地小劇場』の中で、「客席天井の照明室ならびに上手下手のアー チのかげやプロセニアムのかげより舞台にむけて光線をおくり、舞 台天井からは、ボーダー・ライトよりサスペンション・スポットを 多く用いる等々当時としてはざんしんなこころみが大胆に行われた のである。」47と述べている。これらの言説から、舞台両端に設け られたアーチの中に照明設備があると推測されるが、昭和 8 年の改 築写真を見ると、舞台前両端にスポットライトが客席からも確認で きるように設置されている。下線(2)は、ホリゾント (コンクリート によるクッペルホリソント）の設置を指している。これは舞台の中 で照明を構築しようとした、ドイツを中心としたポータルなどを設 罳する照明方法で、FOHの発達との方向性とは逆の行き方である。 当時としては、むしろクッペルホリゾントを使用した照明効果を発

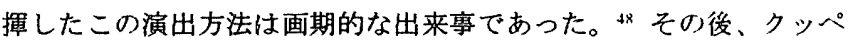
ルホリゾントは名古屋市公会堂、早稲田大学大涱講堂、東京朝日新 開社檴堂に設置されている。

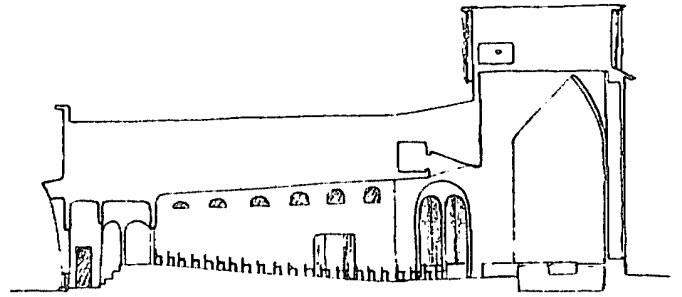

図3.栄地小劇場断面図；機関詰『築地小劇場』㓣刊号口絵

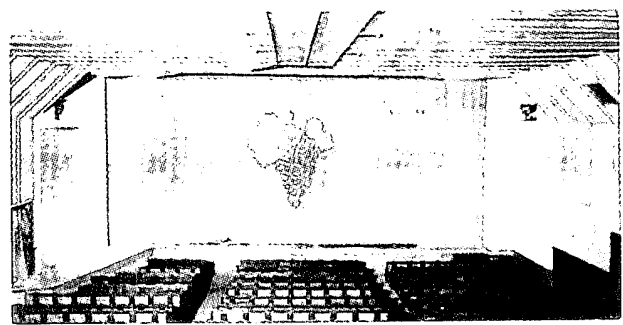

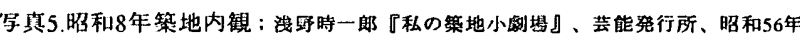

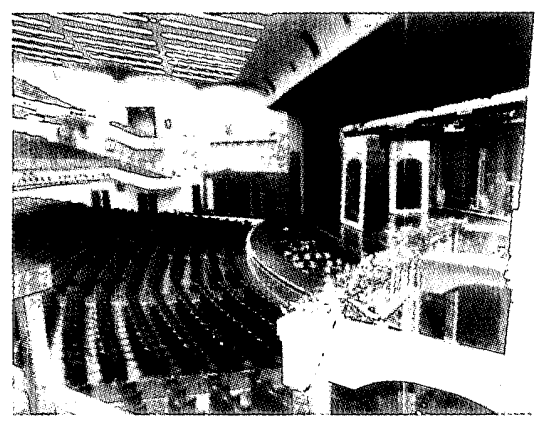

等真6。東京突塚劇場調光室より（平成9年著者撮影)

4. 築地小劇場の空間構成にみる近代的側面について

大正13年から昭和に至るとき、すでにヨーロッパではホリソン トと照明の関倸だけでなく、グローセスシャウシュピールハウス に見られるように新しい空間の提案まで済ませていた。しかし築 地において舞台と客席とを融合させるという試みは、前舞台領域 における構造的なあるいは意匠的な処理が舞台前両脇舞台と客席 に繁がる3段の階段による処理に対し舞台両劦のアーチの影からの

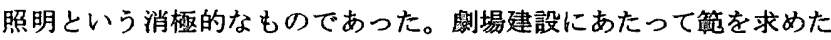
劇場に、ギリシャ劇場、シェイクスピア钊場、グローセスシャウ シュピールハウス、ビューュロンビエ座、カメルヌイ劇埸、メイエ ルホリドの劇場などの名が挙がっているが、40 具体的にどの劇場の どの部分を模したかという記録はない。しかし、土方与志著『演出 者への道』に若干記されている、即ち、

「舞台、観客席は、私のしばしば出入りしたベルリンのカンマシュ ピーレ座による所が多い。問題のクッペルホリゾントもほとんどが その形をとり、観客席と舞台の高さもそれに等しい。（中略）かつ ての舞台の左側（客席より）にあった照明室が、次第に王侯貴族の 見物たりし第一ボックスに移りつつある傾向から、築地小很場も照 明の中心を観客席の上に持って来たのである! 50 


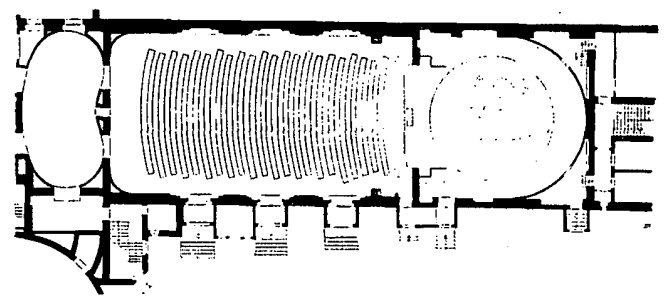

図4.カンマシュピーレ座平间図

出典 : HARALD ZIELSKE,DEUTSCHE THEATERBAUTEN BIS ZUM ZWEITEN WELTKR IEG,Selbstverlag der Gesellschaft für Theatergeschichte, 1971,p.253

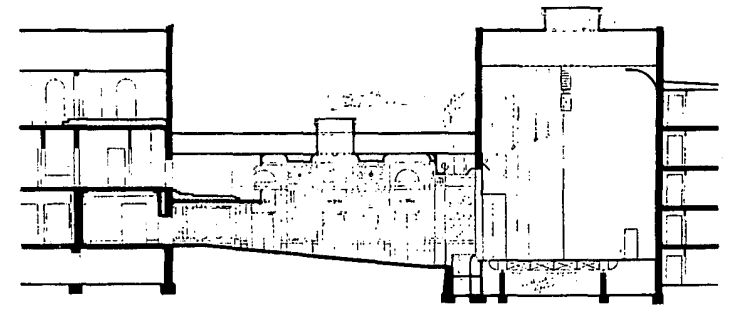

図5.カンマシュピーレ座断面図；怙典：図4に同じ,p.253

「演劇の実験室」と銘打った築地小劇場での上演に、一定した戯曲の 選択がないことからもわかるように51、ここではリアリズムや構成主 義、表現主義などあらゆる演出上の手法に対忍できるようフレキシビ リィティを持たせる意図が含まれている。従って、築地における劇場 空間が具体的にどの部分を模したのかといら復元的考察よりは、その 実行に移された空間的処理に日本的変遷を見るという立場を採りた い。以下に、プロセニアムアーチを採用したとともに、舞台と客席と の関倸に対する近代的側面を3点に要約して列挙する。

1）舞台をどの客席からも視界を良好にするその解決として舞台前 から客席に向かい同じ幅の階段客席の設置

2）群衆の出入りなどに使用のため、舞台両端左右各二個のアーチ の設置及び斜めに客席に突き出た舞台（花道）

3）客席前列を取り外して前舞台とする

1）は遠近法に準じた一方向性への指向と見ることができる。2） は演出の重要性に基づく群集の扱い一の配慮及び、プロセニアム アーチを逸脱する目論見と見られる両脇アーチと両脇舞台、3）は プロセニアムアーチがありながらも舞台と客席の融合を見る前階段 の設置（アメリカの小劇場などにみる近代の特徽と言える）。この ように、舞台と客席との融合を図る形態としての跡が見られると同 時に、舞台と客席とを隔離するプロセニアムアーチを利用した第四 の壁理論を演劇界に定着させたのもこの劇場である。築地で行われ たのは、歌舞伎劇場に見られた花道を有する空間ではなく、新劇を 上演する場として有楽座に見られたプロセニアムアーチを尊入した 洋風空間を、さらに我が国初のクッペルホリゾントを有し、客席前 天井に投光室を設けるなど舞台照明の分野を押し進めた形を取っ た。また付属の劇団に、舞台芸術の古実に導く様々な部署を創設し たことにも特徴があり、それが現代の演出、舞台美術の分野に基碄 を築いたという功續はある。しかし、歌舞伎や新派とは違う「新し い劇」を目指したこの時期には、西洋において日本の花道を採用し た舞台が行われたという記述52もあるほど花道は迴り舞台とともに 日本の舞台の特徵であり、当時の脱歌舞伎に向かった者でも、花道 を舞台と客席の融合を果たす構造的手段として認識していた。小山 内董が望む「花道の新しい使い方」を実現させるという意向に沿っ
て仮設でも歌舞伎劇場の見られるような花道設置とは至らず、ま た花道の明確な理念的位固づけに関する記述は見当たらない。た だ、小山内の以下の花道に関する言説には、「花道不要論」は窥 われない。

「私達は私達の唯一の誇りである「花道」を尚一層芸術的に為上 げなければならぬ。「迴り舞台」に進歩があったやうに「花道」 にも進歩はあるに違ひない。（中略）私は窃に心配する。「迴り 舞台」で西洋に負けた日本が、また「花道」で西洋に負けるやう な時が来なければ好いがと。」53

小山内薰は花道の新しい使い方を考える用意はできており、海外 でも同時代に花道への関心がもたれた形跡もあるが、築地では花 道は舞台の延長としてわずかに両脇舞台として併設されたにすぎ ない。舞台と客席との融合を求める手段として前舞台領域を照ら 寸ということについては、大正13年開場当時は舞台前両端のアー チの影からの投光といら消極的なものから、昭和 8 年の改築時に 至ってようやく客席から見える形でフロントサイドスポットが設 置されたという経緯はあるにしろ、遠山自身も既に述べたように 築地は照明設備の新設に当たってその意義を演劇的重要性として 念頭に入れて設計に当たったことを認めている。築地はクッペル ホリソントを採り入れ、舞台内に照明を満たすという方向性とと もに、前舞台領域の処理を写真でみるように客席への融合を指向 するようなスペースが設けられるという両者の共存を内包し昭和 を経過する。

5. 結論

明治末期より昭和期に至る劇場空間の変化は、歌舞伎の劇場形 式に新たなジャンル（新镬）が加わることによって二つの方向性 を内包した。両者は構造的に逆の方向性をもつ。花道の存在有無 及びプロセニアムアーチの存在による第四の壁理論の採用であ る。空間内共存の結果、前舞台領域における構造的変化は、客席 に進入する花道との境界領域の後退に象徵される。歌舞伎の劇場 空間は震災後、鉄筋コンクリート造が採用されることによって、 プロセニアムアーチによる舞台と客席の区画が強化され、大臣柱 と舞台端の空間が消滅し大臣柱は装置的に扱われるようになる。 照明に関しては、歌舞伎劇は基本的に平面的で絵画的なため均質 に照らされる必要があり、レビュー劇場の建設でFOHからの投光 が優先されるという経緯を辿った。一方、新劇は立体的な表現へ と進み、築地に見られる新劇の空間では、クッペルホリゾント、 ルントホリゾントを使用して舞台内で完結させる照明方法の探求 が行われると同時に、前舞台のスペースと前明かりを用意すると いう共存した空間構成は我が国の独特の空間構成を示すものであ ク、日本の空間構成における異ジャンル共存の歴史の端緒的存在 であると言える。

注：

I.FOH（Front of house）劇場における䘽客席を意味する。プロセニアムよ り前方の客席、立関、ロビー、儌下、搭带品預㹞、切符売場、食堂など表

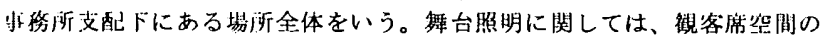
みを急味する。正確にいえば、front of house light と称して、客席側から 器台に投毕する照明を言う。 


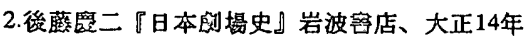

3.須田敦夫『日本钢揭史の研究』、相模害房、昭和32年

4.竹内芳太郎『日本即場图史』、王生害院、昭和10年

5.佐藤武夫『オーティトリアム』、新建築譐座、1929年

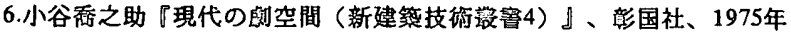

7. 清水裕之『测堨の權図』、鹿島出版会、昭和60年

8.景山竫雄『舞台照明学上下巻』、リブロポート、1988年

9.大正9年没。当時の首相伊臀博文の長女之結婚。

10.菅井幸雄『近代日本演剆詥争史』、未来社、1979年、pp.8-15

11.末松諮澄『演剆改良全』、文学社、明治19年、pp.36 37

12.新聞『中外商業』、明治44年7月11日

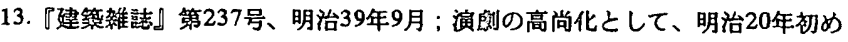
て天監剆が上演されているが、基本的に政府の嗳助はない。

14.杉浦善三『帝的十年史』、玄文社、大正9年、p.200

15.新閪『冤気日報』第干六百六十二号、大正十五年二月九日

16.三宅周太郎『演恻五十年史』、昭和 17 年、p.124

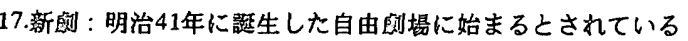

新派：明治21年大阪の「壮士芝居」「害生芝居」など同時代の流れをくむ

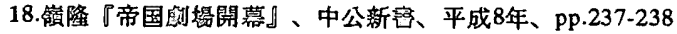

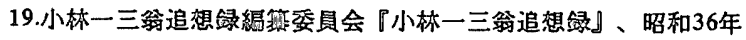

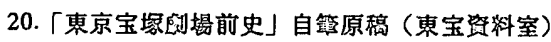

21.太田正雄『木市莝太郎全急』第十九巻（『地下一尺纂』を底本）、岩波害 店、1982、pp.329-334、クウルト・グラアザ : ベルリン博物館員、明治44年 訪日。明治45年 (1912) 4月7日『読売新闕』記恄

22.河竹登志夫『演利概諭』、東京大学出版会、pp.175-176

23.滑水裕之『日本の刢場空間』「空間の生成と変容に関するノート」、日本 の美学第16号、ペリカン社、1991年、pp.120-137

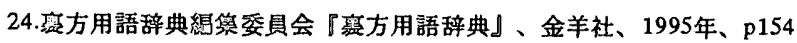

25. 杉浦善三『帝則十年史』、大正 9 年、p.12

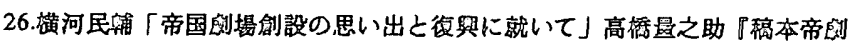
の回想』に収録

27.島村抱月『抱月全篡』、大正6年1、2月、pp.637 663

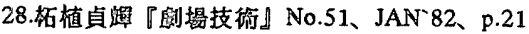

29.日本报初のレビューとされている「モン・パリ」の振り付けを担当。この 作品でラインダンが行われ、大階段が初めて使われたとされている。この 作品から我が国はレビュ一時代に入り、同時に小校一三の大挒堨諭の成功を

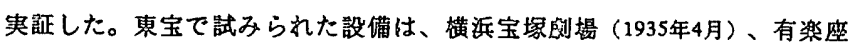

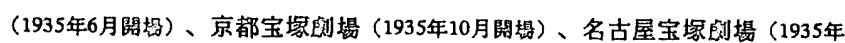
11月開均)など東宝系各師場に引き継がれる。

30.白井铁造『宝焃之私』、中林出版、1967年、p.80

31.設計施工 - 合名会社竹中工呚店／設計 就尾九郎 石川純一郎、小栙利助 ／工亭主任 大内二男／現場主任 小能佐吉／樈造計等及び監䝳 工学博士

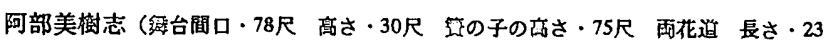

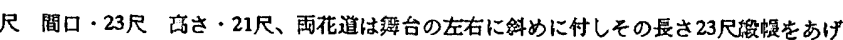

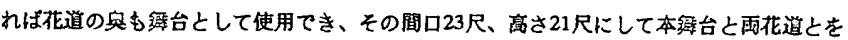

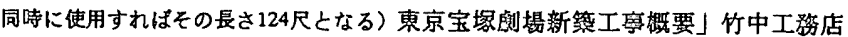
曺京支店、昭和9年1月、p.12

32.国際飤場開場に際し、東京宝塚到堨、日本剆場、大阪歌舞伎座、アメリカ などを調䆟。

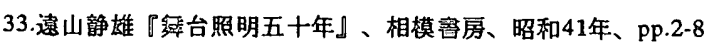

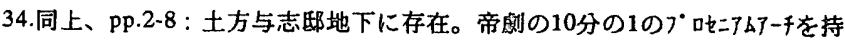

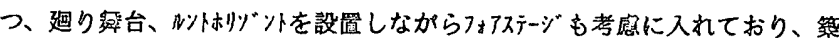
地の前身的性络を示している。

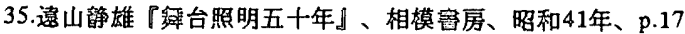

36.37德山觧雄『经台照明学下巻』、リブロポート、1988年、pp.126-130

38.遠山铮雄『舞台照明五十年』、相模害房、昭和 41 年、p.18

39.同上、 $\mathrm{p} 33$

40.『日本台台テレビ照明近代史』、日本照明家協会、平成 5 年、p.8

41.『日本经台テレビ照明近代史』日本照明家協会、平成5年、pp.8-9

42.貴察室の設置は帝国的場をもって壦矢

43. 北藻䋗主任で約10名が背景の西洋画（油绘）を担当。それ以前には、明治

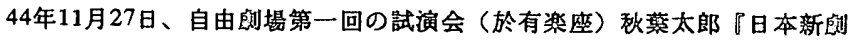
史』によれば、「和田、北、中沢弘光及ひ美術学慗卒業生效名加背景。明治 座電気係松井新（阿久理太郎：遠山竫雄推測）、美術学校教授古宇田実が建 筷方面をそれぞれ担当とある。注・33に同し、pp.2-4 44.杉溥旁三『帝荗十年史』、玄文社、大正9年、p.23

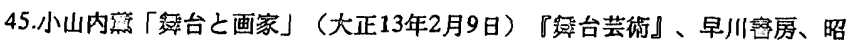
和23年、 .204

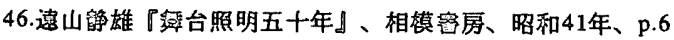

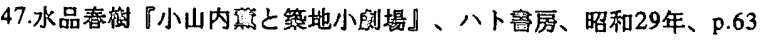

48.その後の改笾で、使用の便利さからッ栦ットとなる

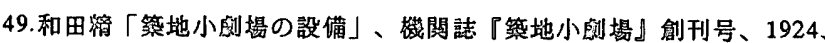
pp. $70-79$

50.土方与志『演出者への道』、未来社、1969年、p.156

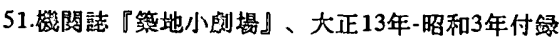

52.小山内望『芝居入門』、プラトン社、大正13年、p.126

53.同上、p.128

参考文献 :

1.外山正一『演到改良諭私考』、丸善蜜店、明治19年

2. 来松設澄『演勋改良意見全』、文学社、明治19年

3.小山内等『演创新声』、曺堂、明治45年

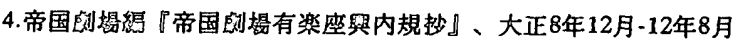

5.小林一三『日本歌即諭』、宝挥少女歌刻团、大正14年

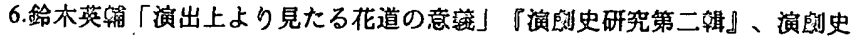
学会、昭和8年

7.『日本即場』、林式会社大林組、昭和 9 年

8.『新建筑」第10巻第 1 号、新起筑社、昭和 9 年

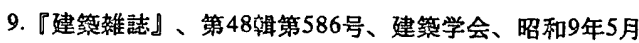

10.建筑写真䅡聚第十期第三倝『珟場之映画館』、洪洋社、昭和 12 年

11.横河民的追想绿刊行会『横河民辣追想録』、技報堂、昭和 30 年

12.北村志八『演出入門」、䈔ヶ関筧房、昭和 21 年

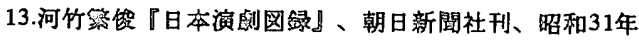

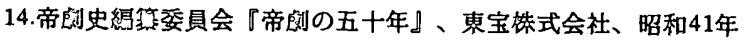
15.小川昇螕著『補訂日本舞台照明史』、日本盟明家協会、昭和50年

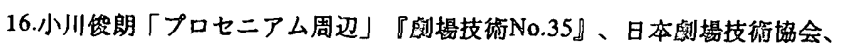
1978年

17.河竹登志走『歌吱伎美敦』、東京大学出版会、1989年

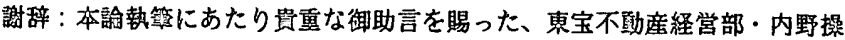

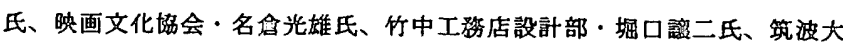

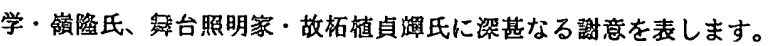
(1998年 3 月 10 日原稿受理, 1998年 8 月21 日採用決定） 